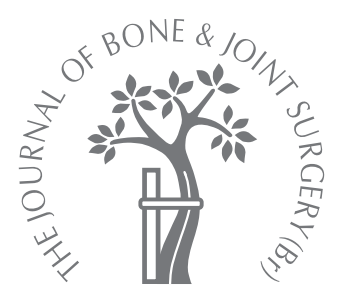

H.-C. Pape, P. Giannoudis

From the University of Pennsylvania, Pittsburgh, USA

H.-C. Pape, MD, Associate Professor

Department of Orthopaedic Surgery

Pittsburgh Medical Centre, 3471 Fifth Avenue, Suite 1010, Pittsburgh, Pennsylvania 15213, USA.

- P. Giannoudis, MD, Professor of Trauma and Orthopaedic Surgery

Department of Trauma and Orthopaedics

St James's University Hospital, Beckett Street, Leeds LS9 7TF,

UK.

Correspondence should be sent to Professor H.-C. Pape; e-mail: papehc@upmc.edu

(C)2007 British Editorial Society of Bone and Joint Surgery doi:10.1302/0301-620X.89B11. $19570 \$ 2.00$

$J$ Bone Joint Surg [Br] 2007;89-B:1421-6.
- ASPECTS OF CURRENT MANAGEMENT

\section{The biological and physiological effects of intramedullary reaming}

\author{
This paper summarises the current knowledge on the effects of medullary reaming of long- \\ bone fractures. Following a review of intramedullary vascular physiology, the \\ consequences for vascularity, the autograft effects, the generation of heat, and fat \\ embolism are outlined. Also, alternative reaming techniques are described.
}

The development of intramedullary nailing, introduced in 1939 by Küntscher, ${ }^{1}$ revolutionised the treatment of fractures of the long bones. Initially, this mechanism of stabilisation consisted of the maintenance of close contact and friction between the implant and the inner cortex by a cloverleaf nail. The technique was limited to simple fractures of the midshaft only. Once established, reaming became an important addition to the method. The process of reaming has attracted extensive research and has been shown to be associated with a number of biological effects, including the alteration of the medullary blood supply, fat embolisation, autografting and the generation of thermal energy. ${ }^{2-6}$ Since the development of locked nailing, the indications for intramedullary stabilisation have been expanded further, thus providing a broad spectrum of options for the management of a variety of fractures. ${ }^{7}$ This review describes the anatomy and physiology of intra- and extramedullary changes induced by reaming of the medullary canal in fractures of the long bones.

\section{The kinetics of the intramedullary blood supply}

The intramedullary vascular anatomy has been described extensively. The arterial and the venous systems are described separately.

The arterial system. There are three different vascular trees within the arterial system, namely, the nutrient artery and its branches, the perforating metaphyseal and epiphyseal arteries and the periosteal vessels. ${ }^{8-11}$

Periosteal vessels play an important role in the osseous blood supply and variations in different parts of the shaft of the femur have been described. ${ }^{10}$ An experimental study by
Nutz ${ }^{12}$ showed that there was a better blood supply in the proximal shaft of the femur compared with the distal portion. A nutritent artery usually enters the cortex of the diaphysis of the femur in the area of the linea aspera ${ }^{11}$ and communicates with further medullary arteries. These form anastomoses both proximally and distally with metaphyseal vessels. ${ }^{8,9}$

The process of intramedullary reaming largely destroys the intramedullary arterial system. ${ }^{2,3}$ A study by Schemitsch et $\mathrm{al}^{4}$ has clearly demonstrated that reaming alters bone perfusion, but that this appears to resolve by three months.

The venous system. This has not been investigated as thoroughly as the arterial system but the intramedullary venous plexus is altered by reaming. The anatomical differences between the arterial and the venous systems were documented as early as 1876 when Langer ${ }^{13}$ noted that "The venous system of long bones is much larger, they are more numerous and their wall is much thinner than the one of arteries".

Other investigations have demonstrated that the venous system may be regarded as a blood pool. The intramedullary veins have been described as 'capacity vessels'. ${ }^{14}$ The presence of a large central vessel, the central venous sinus, has been confirmed and may communicate with wide venous sinusoids, which allow venous pooling. ${ }^{8,15}$ The thin venous wall is very flexible and the venous system is capable of filling up to one-third of the entire medullary canal. ${ }^{15}$ Its capacity is estimated to be six to eight times greater than that of the arterial system of the long bones. ${ }^{16}$ The reported features of the intramedullary veins are listed in Table I. 
Table I. Features of the intramedullary venous vessels

\begin{tabular}{|c|c|c|}
\hline Author/s & Features of intramedullary venous vessels & Effect \\
\hline Langer $^{13}$ & More veins than arteries are present in the medullary canal & Number \\
\hline Écoiffer et al ${ }^{16}$ & $\begin{array}{l}\text { The diameter of the veins is six to eight times greater } \\
\text { than that of arteries }\end{array}$ & Pool function \\
\hline Cuthbertson et al ${ }^{17}$ & Outflow is maintained through the metaphysis & Piston effect \\
\hline Brookes $^{11}$ & The centrifugal blood flow is unrestricted & Shunt function \\
\hline Shaw ${ }^{14}$ & Intramedullary blood flow depends on local pressure & Influence of blood pressure \\
\hline
\end{tabular}

Table II. Experimental and clinical data on measurements of intramedullary pressure during stabilisation of fractures of the femur. The pressure represents the maximum pressures recorded in the investigations

\begin{tabular}{|c|c|c|c|}
\hline Author/s & Localisation & Specimen & Pressure \\
\hline Küntscher $^{1}$ & Femur & Man & $>$ arterial $\mathrm{BP}^{*}$ \\
\hline Rehm $^{19}$ & Femur & Man & 0.33 bar \\
\hline Wehner ${ }^{40}$ & Tibia & Man & $120 \mathrm{mmHg}$ \\
\hline Danckwardt-Lillestrom ${ }^{41}$ & Tibia & Rabbit & $300 \mathrm{mmHg}$ \\
\hline Stürmer and Schuchardt ${ }^{20}$ & Tibia & Sheep & $1500 \mathrm{mmHg}$ \\
\hline Wenda and Runkel ${ }^{6}$ & Femur & Man & $1510 \mathrm{mmHg}$ \\
\hline Peter et al ${ }^{42}$ & Femur (intact) & Man & $450 \mathrm{mmHg}$ \\
\hline Müller et al ${ }^{54}$ & Femur & Man (in vitro) & $800 \mathrm{mmHg}$ \\
\hline Wozasek et al ${ }^{43}$ & Femur & Sheep & $1126 \mathrm{mmHg}$ \\
\hline Hopf et al $^{44}$ & Femur & Man & 0.26 bar \\
\hline
\end{tabular}

* BP, blood pressure

Regulation of the intramedullary blood flow. As in the systemic circulation, a physiological blood flow is present in long bones. It has been measured as $1.3 \mathrm{~mm} / \mathrm{s}$ in the arterioles and $0.1 \mathrm{~mm} / \mathrm{s}$ to $0.3 \mathrm{~mm} / \mathrm{s}$ in the venules. ${ }^{8}$ The intramedullary canal also acts as a supporting pump for venous backflow. ${ }^{14}$

The systemic blood pressure and the general circulatory conditions directly affect local blood flow. The physiological blood flow is also regulated by other passive and active mechanisms, independent of the systemic circulation. Passive changes of intramedullary blood flow. Several independent parameters can influence the medullary blood flow $^{14}$ such as 1 ) changes in inflow due to variation in the systemic blood pressure and muscle blood flow; 2) changes in outflow due to venous obstruction; and 3) pressure changes induced by respiration.

Changes in the inflow of intramedullary blood can induce a vascular shunt phenomenon, which may influence the intravasation of intramedullary contents. The physiological blood flow appears to be more constant in bone than in muscle. The conditions for the production of a shunt are of special interest. Experimental ligation of the femoral vein induces a biphasic response. There is an initial transient reduction of blood flow followed by a period of hyperfusion which appears to affect the bone only and not the muscle.

Active changes of intramedullary blood flow. The regulation of blood flow is also influenced by active, neural and biochemical mechanisms. ${ }^{14}$ The central venous sinus is the most important intramedullary vessel and is extremely distensible. Phlebographic investigation has shown that a major portion of outflow is maintained by additional vessels within the metaphysis (Table I) and that there is free blood flow in both centrifugal and centripetal directions. Therefore every muscular contraction causes a rise in intramedullary pressure. This shunt function is also present in a vertical direction. With a tourniquet at the diaphysis, a venous injection of dye reaches the venous system proximal to the tourniquet through the intramedullary canal. ${ }^{14}$

Under physiological conditions there is centripetal blood flow. With a rise in intramedullary pressure, reversal of the direction of flow may occur. ${ }^{11}$ This may also be induced by the piston-like effect of an intramedullary reamer. Thus, bone marrow, fat or other intramedullary contents may be forced into the metaphyseal vascular systems. ${ }^{17}$ There is a direct relationship between intramedullary pressure and flow. ${ }^{14}$

A physiological positive pressure is present within the medullary canal. This is pulse-dependent and has been found to be approximately $25 \mathrm{mmHg}$ to $30 \mathrm{mmHg}$ in sheep..$^{5}$ Stein, Morgan and Reynolds ${ }^{18}$ recorded mean values of $50 \mathrm{mmHg}$ in the dog and values up to $65 \mathrm{mmHg}$ in man. Other authors have recorded lower values intraoperatively in patients with fractures of the femur. ${ }^{6}$ Rehm ${ }^{19}$ recorded a mean pressure of $27 \mathrm{mmHg}$ in the intact human humerus compared with $6 \mathrm{mmHg}$ on the contralateral side which was fractured.

\section{Intramedullary pressure changes and intravasation of bone marrow}

In order to achieve intravasation of bone marrow or fat into the vascular system, the intramedullary pressure has to be surpassed. The experimental and clinical findings regarding measurements of intramedullary pressure after reaming 
Table III. Volume of intravasated intramedullary contents

\begin{tabular}{lll}
\hline Author/s & Volume effect $(\mathbf{m l})$ & Localisation \\
\hline Vance $^{25}$ & 60 to 80 & Lower limb \\
Küntscher $^{23}$ & 20 & $15 \mathrm{~mm}$ reamer, femur \\
Watson $^{26}$ & 20 to 50 & Femur \\
Wenda and Runkel $^{6}$ & 50 & $15 \mathrm{~mm}$ reamer, femur \\
\hline
\end{tabular}

Table IV. Pathomechanisms of acute intra-operative pulmonary complications

\begin{tabular}{|c|c|c|}
\hline Author/s & Mechanism & Pathophysiological explanation \\
\hline Kallos et al ${ }^{45}$ & Fat embolism & Intravasation, intramedullary pressure rise \\
\hline Saldeen ${ }^{46}$ & Microthrombus & Activation of coagulation by thromboplastin \\
\hline Hofmann et $\mathrm{al}^{47}$ & Air embolism & Air trapped inside the medullary canal \\
\hline Eggert et $\mathrm{al}^{48}$ & Monomer reaction & Toxic reaction of bone cement \\
\hline Schlag et $\mathrm{al}^{49}$ & Vasovagal reflex & Sensitisation of pulmonary extensile receptors \\
\hline
\end{tabular}

in long bones are summarised in Table II. There is widespread agreement concerning the following basic principles: 1) The highest pressure values are achieved during the initial reaming; 2) the maximum pressure increase is achieved after the reamer has entered the main distal fragment since there is no further reduction of pressure by leakage from the fracture line; 3 ) in the course of femoral nailing the reaming procedure produces an increase in intramedullary pressure, but insertion of the nail does not appear to cause a further rise. ${ }^{5,6,20-22}$

The volume effect was discussed by Küntscher. ${ }^{23} \mathrm{He}$ calculated a displacement of $20 \mathrm{ml}$ of water if a nail of $37 \mathrm{~cm}$ in length and $15 \mathrm{~mm}$ in diameter was inserted. However, he did not regard this volume effect as important since intramedullary contents can escape proximally along the slitted nail. He stated that "the effect of subsequent hammer strokes is additive. Therefore pressures by far above diastolic values can occur. It is crucial however, that it takes several seconds until the pressure reduces back to normal levels. In conclusion it appears of uttermost importance to insert the nail as slowly as possible". ${ }^{23}$

Wenda and Runkel ${ }^{6}$ calculated the volume effect on the basis of the reamer rather than the nail. By means of a surface formula he determined a volume effect of $50 \mathrm{ml}$ for a $15 \mathrm{~mm}$ instrument. He concluded that "It does not appear likely that this volume can flow proximally as the drill is advanced". 6

According to current knowledge, the localisation and type of fracture appear to be important for the degree of volume effect. In proximal, simple fractures a greater effect is more likely than that in distal fractures with multiple fragments.

No clinical data are available on this topic but experimental investigations have been undertaken. Manning et $\mathrm{al}^{24}$ demonstrated a greater amount of leakage of fat in intact compared with fractured dog femora. Vance ${ }^{25}$ estimated a volume of fat of $60 \mathrm{ml}$ to $80 \mathrm{ml}$ to be liberated from the lower limbs, while Watson ${ }^{26}$ calculated approximately 20 $\mathrm{ml}$ to $50 \mathrm{ml}$ (Table III).
Our group and others have performed experimental investigations regarding the systemic effects of reaming. The earliest studies were done by Stürmer and Schuchardt ${ }^{20}$ who demonstrated extravasation of fat after reaming. This was confirmed by Wenda et $\mathrm{a}^{21}$ who noted the addition of platelets to the fat thrombus as it travelled through the vena cava. The intact femur has usually been used to detect systemic changes in animal models. Reamed nailing caused pulmonary microvascular damage only in the presence of previous pulmonary injury. The transient vascular changes (pulmonary artery pressure, pulmonary vascular resistance increase) also occurred in isolated femoral fractures in the absence of a lung contusion or other predisposing injuries for adult respiratory distress syndrome and organ failure. ${ }^{27}$ The use of an unreamed nail, ${ }^{28}$ the employment of different reamers ${ }^{29}$ and the application of external fixation ${ }^{28}$ were all able to reduce the vascular and the oedematous changes as determined by the collection of lymph from the lung. In another set of experiments, the coagulation effect was quantified after reaming and was shown to play a role in the development of pulmonary dysfunction. ${ }^{30}$

In a separate model, reamed nailing of an intact femur was used before the induction of other stimuli in the development of a model of irreversible organ failure. The addition of sequential inflammatory stimuli after shock, lung contusion and reamed nailing led to the expected irreversible organ damage. ${ }^{31}$

The response to reamed nailing, unreamed nailing and plate osteosynthesis of fracture of the femoral shaft in sheep with and without lung contusion has also been investigated. Reaming caused a reversible increase in pulmonary vascular resistance, but no sustained pulmonary dysfunction despite lung contusion. It was therefore concluded that lung contusion did not prime the lung for further deterioration and that reamed nailing was not harmful. ${ }^{32}$

The particular animal model selected may play a role. ${ }^{33-35}$ Currently, the baboon model used by Kröpfl et $\mathrm{al}^{36}$ appears to be the best comparison with the human situation. In this model, reamed nailing caused a higher degree 
of fat embolisation than unreamed nailing. This agreed with a clinical study which indicated a higher degree of inflammatory response after reamed nailing. ${ }^{37}$ It also confirmed our previous results using a reamer irrigator aspirator technique. ${ }^{38}$ Whatever the effect of reaming, it appears that a modulation may occur if there is additional chest trauma or haemorrhagic shock. In these cases, the effects are accentuated and may have more clinical relevance. Therefore, the general recommendation has been to proceed carefully when reaming is performed. ${ }^{39-44}$ Further data are given in Table IV. ${ }^{45-49}$

\section{Generation of heat}

During reaming rises in temperature of more than $50^{\circ} \mathrm{C}$ have been reported. ${ }^{50,51}$ This can lead to thermal necrosis of bone with alteration of endosteal architecture and biological failure. ${ }^{52}$ The critical temperature for thermal injury of bone is considered to be $56^{\circ} \mathrm{C}$ which is the level at which denaturation of alkaline phosphatase occurs, but extensive cortical necrosis has been reported at temperatures higher than $70^{\circ} \mathrm{C} . .^{53}$ Several authors have focused on the effect of intramedullary reaming and rise of temperature, reporting a correlation between the elevation of temperature and the size of the reamer. ${ }^{54}$ Although the complication of thermal necrosis as a result of intramedullary reaming is commonly quoted, clinical evidence of this is rare and fewer than ten cases have been recorded in the literature. ${ }^{55}$ In addition to the injudicious use of reaming, the application of a tourniquet has been considered to be an important factor in thermal necrosis. A recent study, however, indicated that the application of a tourniquet and reaming to $1.5 \mathrm{~mm}$ above the required diameter of the nail appeared to be safe clinical practice. $^{55}$

\section{Autografting by debris from intramedullary nailing} While some of the above factors indicate the potential complications of reaming, the positive factors should be emphasised. Healing after intramedullary stabilisation has received widespread attention, especially since the implementation of the unreamed technique and the use of thin solid nails. In a model of a fracture of the tibia, the effects of reamed versus unreamed nailing were compared. ${ }^{4}$ In the reamed group, tibial fractures induced by three-point bending stress were stabilised by $7.0 \mathrm{~mm}$ nails after reaming up to a diameter of $8.5 \mathrm{~mm}$. At follow-up there was significantly worse perfusion in the proximal and distal fragments and around the site of the fracture until six weeks after the experiment. ${ }^{4}$ In sheep, the debris created during intramedullary reaming was shown to be collected at the fracture gap. This effect was also comparable with conventional bone grafting, thus supporting the theory of 'autografting'. ${ }^{56}$

Reaming mobilises cancellous bone inside the medullary canal. Exchange reamed nailing is a standard procedure in patients with nonunion after fractures. There appears to be stimulation of revascularisation by the breaking-up of intramedullary scar tissue. This may also be effective in patients with chronic osteitis who have episodes of ischaemic pain. ${ }^{57}$

In a recent review Brinker and O'Connor ${ }^{58}$ drew the following conclusions regarding the technique and the indication of reaming and exchange nailing for nonunion: "Exchange nailing is an excellent choice for aseptic nonunions of noncomminuted diaphyseal tibial fractures, with union rates reported to range from $76 \%$ to $96 \%$. Canal reaming should progress until osseous tissue is observed in the reaming flutes. The exchange nail should be at least $1 \mathrm{~mm}$ larger in diameter than the nail being removed, and it has been recommended that it should be up to $4 \mathrm{~mm}$ larger if the nail being removed is greatly undersized. On the basis of the available literature, exchange nailing cannot be recommended for distal femoral nonunions at this time. There is no clear consensus regarding the use of exchange nailing in the presence of active, purulent infection".

Likewise, Hak, Lee and Goulet ${ }^{59}$ concluded that "Exchange reamed nailing remains the treatment of choice for most femoral diaphyseal nonunions. Exchange reamed IM [intramedullary] nailing has low morbidity, may obviate the need for additional bone grafting, and allows full weight-bearing and active rehabilitation".

Recently, new systems have been developed which allow modification of the effects of regular reamers. Irrigation using saline at the tip of the reamer and subsequent suction of the intramedullary contents reduce the risk of embolisation, and with the addition of a strong suction device, the intramedullary contents may be harvested in a seal. Although no clinical published studies are available at this time, this method may allow the use of reamers in the harvesting of bone grafts. As a source of autologous bone graft, the pelvis offers limited amounts. Moreover, fractures of the anterior iliac spine and complaints of sustained pain at the site of harvesting of the graft have been noted. The volume of medullary bone graft is larger and recent investigations have clearly documented higher concentrations of growth factor in femoral as opposed to pelvic bone grafts. ${ }^{60}$ However, clinical evidence from larger studies has yet to prove the efficacy of these systems.

\section{Effect on the vitality of cell populations and release of growth factors}

With the latest advances in diagnostic techniques in molecular biology there has been considerable interest in the effect of reaming on the cell populations normally found in the intramedullary canal. Some authors have shown that the reaming debris is a source of multipotent stem cells which can grow and proliferate in vitro. ${ }^{61,62}$ This has prompted interest in the use of these stem cells in cell and bone replacement therapy. ${ }^{61,62}$ The release of molecular mediators implicated in fracture healing has been investigated after reaming. In a quantitative assessment of growth factors in reamed aspirate, elevated levels of several growth factors were found in the debris as compared with bone 
from the iliac crest. ${ }^{63}$ The process of reaming induced an increased release of further growth factors by $111.2 \%$ and $115.6 \%$, respectively. IGF-1 also increased by $31.5 \%$ and TGF-b1 by $54.2 \%$. The authors concluded that reaming of the intramedullary canal was associated with an increased liberation of growth factors and that the osteogenic effect of reaming could be secondary not only to the graft debris, but also to the increased liberation of these molecules.

In summary, reaming of the canal of long bones alters the medullary blood flow, blood supply and rate of healing. It has led to an expansion of the indications for nailing in fractures of the long bones. These effects are also of value in nonunion, and for relief of pain in patients with chronic osteitis. Modern reaming techniques may allow eradication of concern regarding embolisation of bone-marrow contents and offer the additional option of their use as a boneharvesting device.

\section{References}

1. Küntscher G. Die Marknagelung von Knochenbrüchen. Arch F Klin 1940;200:443.

2. Klein MPM, Rahn BA, Frigg R, Kessler S, Perren SM. Reaming versus nonreaming in medullary nailing interference with cortical circulation of the canine tibia. Arch Orthop Trauma Surg 1990;314:314-16.

3. Mueller CA, Rahn BA, Muller C. Intramedullary pressure increase and decrease in cortical temperature during reaming of the femoral medullary cavity: the effect of draining the medullary contents before reaming. J Trauma 2003;55:495-503.

4. Schemitsch E, Kowalski M, Swiotkowski M, Senft D. Cortical bone blood flow in reamed and unreamed locked intramedullary nailing: a fractured tibia model in sheep. J Orthop Trauma 1994;8:373-82.

5. Stürmer KM, Schuchardt W. New aspects of closed intramedullary nailing and marrow cavity healing in animal experiments. II: intramedullary pressure in marrow cavity remains (authors transl). Unfallheilkunde 1980;83:346-52 (in German).

6. Wenda K, Runkel M. Systemic complications in intramedullary nailing. Orthopade 1996;25:292-9

7. Hansen ST, Winquist RA. Closed intramedullary nailing of the femur: Küntscher technique with reaming. Clin Orthop 1979;138:56-61.

8. Kelly PJ. Anatomy, physiology and pathology of the blood supply of bones. J Bone Joint Surg [Am] 1968;50-A:766-83.

9. Trueta J, Caladias AX. A study of the blood supply of the long bones. Surg Gynecol Obstet 1964:118:485-98.

10. Macnab I, De Haas WG. The role of periosteal blood supply in the healing of fractures of the tibia. Clin Orthop 1974;105:27-33.

11. Brookes M. The blood supply of bone. London: Butterworths, 1964:91-125

12. Nutz V. Differential circulatory value of various femoral shaft areas: experimental studies in rabbits. Langenbecks Arch Chir 1988;373:206-13 (in German).

13. Langer K. Über die Gefäbversorgung von Röhrenknochen. In: Denkschriften der kaiserlichen Akademic der Wissenschaften. Aus der kaiserlich königlichen Hof-und Staatsdruckerei/Wien 1876;36:1-40.

14. Shaw NE. Observations on the physiology of the circulation in bones. Ann Royal Col Surg 1964:214-33.

15. Morgan JD. Blood supply of growing rabbits tibia. J Bone Joint Surg [Br] 1959;41 B:185-203.

16. Écoiffer J, Prot D, Griffie R, Carach D. Étude du reseau veineux dans le os longs du lapin. Rev Chir Orthop 1937;43:20-37.

17. Cuthbertson EM, Siris E, Gilfillan RS. The femoral diaphyseal medullary venous system as a venous collateral channel in the dog. J Bone Joint Surg [Am] 1965;47A:965-74.

18. Stein AH, Morgan HC, Reynolds FC. Variations in normal bone marrow pres sures. J Bone Joint Surg [Am] 1957;39-A:1129-34.

19. Rehm J. Experimental research on the origin of fat embolism in bone fracture. Lan genbecks Arch Klin Chir Ver Dtsch Z Chir 1957;285:230-8 (in German).

20. Stürmer KM, Schuchardt W. New aspects of closed intramedullary nailing and marrow cavity reaming in animal experiments. I: the tibia of the sheep as a model fo intramedullary nailing (authors transI). Unfallheikunde 1980;83:341-5 (in German).

21. Wenda K, Ritter G, Degreif J, Rudigier J. Pathogenesis of pulmonary complications following intramedullary nailing osteosynthesis. Unfallchirurg 1988;91:432-5 (in German).
22. Wozasek GE, Simon P, RedI H, Schlag G. Intramedullary pressure changes and fat intravasation during intramedullary nailing: an experimental study in sheep. J Trauma 1994:36:202-7.

23. Küntscher G. Die Margnagelung. Berlin: Dr. Werner Saenger Verlag, 1950:77-95.

24. Manning JB, Bach AW, Herman CM, Carrico CJ. Fat release after femur nailing in the dog. J Trauma 1983;23:322-6.

25. Vance BM. The significance of fat embolism. Arch Surg 1931;23:426

26. Watson AJ. Genesis of fat emboli. J Clin Path 1970;23:132-42.

27. Pape HC, Regel G, Tscherne H. Local and systemic effects of fat embolization after intramedullary reaming and its influence by cofactors. Techniques in Orthopaedics 1996;11:2-13.

28. Pape H, Dwenger A, Regel G, et al. Pulmonary damage after intramedullary femoral nailing in sheep: is there an effect of different nailing methods? J Trauma 1992;33:574-81

29. Pape H, Dwenger A, Grotz M, et al. Does the reamer type influence the degree of lung dysfunction after femoral nailing following severe trauma? J Orthop Trauma 1994:8:300-9

30. Pape HC, Bartels M, Pohlemann T, et al. Coagulatory response after femoral instrumentation after severe trauma in sheep. J Trauma 1998;45:720-8.

31. Pape H, Grotz M, Reamers D, et al. Multiple organ failure (MOF) after severe trauma: a sheep model. Int Care Med 1998;24:590-8.

32. Duwelius P, Huckfeldt R, Mullins R, et al. The effects of femoral intramedullary reaming on pulmonary function in a sheep lung model. J Bone Joint Surg [Am] 1997;79-A:194-202.

33. Frolke JP, Van de KH, Bakker FC, Patka P, Haarman HJ. Destination of debris during intramedullary reaming: an experimental study on sheep femurs. Acta Orthop Belg 2000;66:337-40

34. Schemitsch E, Turchin D, Anderson G, et al. Pulmonary and systemic fat embolization after medullary canal pressurization: a hemodynamic and histologic investigation in the dog. J Trauma 1998;45:738-42.

35. Reikeras $\mathbf{0}$. Cardiovascular reactions to intramedullary reaming of long bones in dogs. Acta Anaesthesiol Scand 1987;31:48-51.

36. Kröpfl A, Davies J, Berger U, Hertz H, Schlag G. Intramedullary pressure and bone marrow fat extravasation in reamed and unreamed femoral nailing. J Orthop Res 1999;17:261-8

37. Giannoudis PV, Smith RM, Bellamy MC, et al. Stimulation of the inflammatory system by reamed and unreamed nailing of femoral fractures: an analysis of the second hit. J Bone Joint Surg [Br] 1999;81-B:356-61.

38. Pape HC, Zelle BA, Hildebrand F, et al. Reamed femoral nailing in sheep: does irrigation and aspiration of intramedullary contents alter the systemic response? J Bone Joint Surg [Am] 2005;87-A:2515-22.

39. Olerud S. The effects of intramedullary reaming. In: Browner BD, ed. The science and practice of intramedullary nailing. Philadelphia: Lippincott Williams and Wilkins, 1987:54-91

40. Wehner W. Ablauf der experimentellen Fettembolie. In: Die Fettembolie. Berlin: Verlag Volk and Gesundheit, 1968.

41. Danckwardt-Lilliestrom G. Reaming of the medullary canal and its effect on diaphyseal bone: a fluoroscopic microangiographic and histologic study on the rabbit tibia and dog femur. Acta Orthop Scand Supp/ 1969;128:1-153.

42. Peter RE, Selx T, Koestli A.Influence of the reamer shape on intraosseous pressure during closed intramedullary nailing of the unbroken femur: a preliminary report. Injury 1993;24(Suppl 3):48-55.

43. Wozasek GE, Thurnher M, RedI H, Schlag G. Pulmonary reaction during intramedullary fracture management in traumatic shock: an experimental study. $J$ Trauma 1994;37:249-54.

44. Hopf T, Gleitz M, Hess T. Intramedullary pressure in the femur during boring and nailing with modern compression interlocking nails: risks of fat embolism? Unfallchirurg 1994:97:458-61 (in German)

45. Kallos T, Enis JE, Gollan F, Davis JH. Intramedullary pressure and pulmonary embolism of femoral medullary contents in dogs during insertion of bone cement and a prosthesis. J Bone Joint Surg [Am] 1974;56-A:1363-7.

46. Saldeen T. Intravascular coagulation in the lungs in experimental fat embolism. Acta Chir Scand 1969;135:653-62.

47. Hofmann AA, Wyatt RWB, Gilbertson AA, Dekoss L, Miller J. The effect of air embolization from the femoral canal on hemodynamic parameters during hip arthroplasty. Clin Orthop 1987;218:290-6.

48. Eggert A, Huland H, Ruhnke J, Seidel H. Penetration of methylmethacrylatemonomer in blood circulation following hip joint prosthesis surgery in man. Chirurg 1974;45:236-42 (in German).

49. Schlag G, Schliep HJ, Dingeldein E, Grieben A, Ringsdorf W. Does methylmethacrylate induce cardiovascular complications during alloarthroplastie surgery of the hip joint? Anaesthetist 1976;25:60-7 (in German) 
50. Baumgart F, Kohler G, Ochsner PE. The physics of heat generation during reaming of the medullary cavity. Injury 1998;29(Suppl 2):11-25.

51. Giannoudis PV, Snowden S, Matthews SJ, Smye SW, Smith RM. Temperature rise during reamed tibial nailing. Clin Orthop 2002;395:255-61.

52. Ochsner PE, Baumgart F, Kohler G. Heat induced segmental necrosis after reaming of one humeral and two tibial fractures with a narrow medullary cavity. Injury 1998;29(Suppl 2):1-10.

53. Flory PJ, Garrett RR. Phase transitions in collagen and gelatine systems. J Am Chem Soc 1958;80:4836-45

54. Muller C, McIff T, Rahn BA, Pfister U, Weller S. Intramedullary pressure, strain on the diaphysis and increase in cortical temperature when reaming the femoral medullary cavity: a comparison of blunt and sharp reamers. Injury 1993;24(Suppl 3):22-30.

55. Giannoudis PV, Snowden S, Matthews SJ, Smye SW, Smith RM. Friction burns within the tibia during reaming: are they affected by the use of a tourniquet? J Bone Joint Surg [Br] 2002;84-B:492-6.

56. Frolke JP, Bakker FC, Patka P, Haarman HJ. Reaming debris in osteotomized sheep tibiae. J Trauma 2001;50:65-9.
57. Pape H.-C., Zwipp H, Regel G. Chronic treatment refractory osteomyelitis tubular bones: possibilities and risks of intramedullary boring. Unfallchirurg 1995;98:139-44 (in German).

58. Brinker MR, O'Connor DP. Exchange nailing of ununited fractures. J Bone Joint Surg [Am] 2007;89-A:177-88.

59. Hak DJ, Lee SS, Goulet JA. Success of exchange reamed intramedullary nailing for femoral shaft nonunion or delayed union. J Orthop Trauma 2000;14:178-82.

60. Schmidmaier G, Herrmann S, Green J, et al. Quantitative assessment of growth factors in reaming aspirate, iliac crest, and platelet preparation. Bone 2006;39:115663.

61. Wenisch S, Trinkaus K, Hild A, et al. Human reaming debris: a source of multipotent stem cells. Bone 2005;36:74-83.

62. Hoegel F, Mueller CA, Peter R, Pfister U, Suedkamp NP. Bone debris: dead matter or vital osteoblasts. J Trauma 2004;56:363-7.

63. Giannoudis PV, Pountos I, Morley J, Perry S, Pape HC.The effects of intramed ullary nailing on the release of growth factors. Presented at AAOS, San Diego, California, February 2007 